\title{
Broadcasting Football Rights in Brazil: The Case of Globo and "Club of 13" in the Antitrust Perspective
}

\author{
César Mattos \\ Consultor da Câmara dos Deputados \\ Endereço para contato: Câmara dos Deputados, Anexo III - Gabinete 50 \\ CEP: 70160-900 - Brasília - DF \\ E-mail: cesar.mattos@camara.gov.br
}

Recebido em 14 de outubro de 2011. Aceito em 04 de janeiro de 2012.

\begin{abstract}
In 2010, the Brazilian Antitrust Authority -CADE- concluded an agreeement with Globo and the "Club of 13" on a three-year deal for the exclusive broadcasting rights to all Brazilian Football League (BFL) games spanning the five principal media platforms: freeto-air TV, pay TV, Pay per View, Internet and Mobile. The deal eliminates competition in broadcasting of Brazilian League games (primarily other networks, including Record, SBT, ESPN, etc.), reducing "competition in the market." However, it is plausible to assume that exclusivity can bring efficiencies to the market by ensuring a return on investments. In addition, the sale of broadcasting rights accounts for nearly $40 \%$ of the revenues of Brazilian clubs. Banning exclusivity will likely reduce revenues and dampen sector efficiency. However, the contract included a preference clause for Globo that adversely affected "competition for the market." Globo abandoned the preference clause under the agreement. Another important provision of the agreement was the requirement that the Club of 13 auction the five media platforms separately. This article examines the economic rationale of the agreement and provides a brief analysis of the main lessons arising from the fragmentation of negotiations in 2011.
\end{abstract}

\section{Keywords}

football, exclusivity, auction, TV game broadcasting

\section{JEL Classification}

L41, L44, L83

\section{Resumo}

O Conselho Administrativo de Defesa Econômica - CADE - entrou em acordo com a Globo e o chamado "Clube dos 13" em 2010 acerca da exclusividade de três anos no contrato de venda de direitos de transmissão dos jogos do campeonato brasileiro, englobando as cinco mídias relevantes: TV aberta, TV fechada, Pay per View, Internet e Celular. A prática exclui outros competidores do mercado de transmissão de jogos de futebol do campeonato brasileiro (no caso, principalmente, outras emissoras ou canais como Record, SBT, ESPN, etc..), comprometendo a "concorrência no mercado". No entanto, é bastante plausível assumir que a prática de exclusividade neste mercado 
pode ter eficiências ao garantir o retorno de investimentos. Ademais, as receitas geradas pela cessão dos direitos de transmissão constituem hoje cerca de $40 \%$ das receitas dos clubes brasileiros. A remoção da prática de exclusividade pode reduzir os valores pagos, além de comprometer a eficiência do setor. De outro lado, o contrato também continha "cláusula de preferência" em favor da Globo, mitigando a "concorrência pelo mercado". No acordo, a emissora abriu mão da cláusula de preferência. Outro dispositivo importante do acordo foi obrigar o clube dos 13 a leiloar as cinco mídias principais separadamente. A ideia do artigo é examinar a racionalidade econômica do acordo e uma breve análise das principais lições da fragmentação das negociações que acabou por ocorrer em 2011.

\section{Palavras-Chave}

futebol, exclusividade, leilão, transmissão de jogos por televisão

\section{Introduction}

The relationship between sports and media is increasingly intertwined throughout the world, and in Brazil this is no different. As the Economist (2010) noted, "TV needs sport as much as sport needs $T V$, , as "the wedding between sports and TV has done both parties richer." Boosting the profits of teams and TV requires making viewers and advertisers more willing to pay for the product. This requires a greater focus on the business aspects of this segment.

Jeanrenaud and Késenne (2006) show that the symbiotic relationship between TV and sports is reflected in the fact that revenues from broadcasting emerged as the most important revenue source for several sports. Sports are also key to attracting TV audiences, which affects broadcaster competition. Specifically, football is one of the world's major televised sports (with the significant exception of the US). According to Jeanrenaud and Késenne (2006), broadcasting accounts for $44 \%$ and $37 \%$ of the revenues of English Premier League and Italian Serie $A$ teams, respectively.

In addition, the authors note that the relationship between broadcasters, clubs and advertisers has gone so far as to spur rules changes in some sports: "the possibility of scoring in each exchange in volleyball, the tie-break in tennis and television timeouts in basketball and American football. Equally, organizers have agreed to change the competition schedule to accommodate the needs of broadcasters and sponsors." 
Gratton and Solberg (2007) point out that sports in Europe were heavily regulated until the 1980s. Therefore, sports were largely unattractive to private broadcasters and, as such, mostly televised by State-owned networks. Increasing deregulation since the 1990s has attracted a number of private broadcasters to the business, leading to a substantial rise in the prices of broadcasting rights and greater commercial appeal for advertisers. Moreover, a majority of contests are now broadcast on Pay TV channels, creating an additional revenue stream directly from viewers.

In Brazil, the TV sports business has generated more and more money for teams. Since the mid-1980s, Brazil's leading broadcaster, Globo, has been the sole broadcaster of the country's most important competition, the Brazilian Football League (BFL).

In 1997, a complaint was brought before the Secretariat of Economic Law (Secretaria de Direito Economico - SDE) ${ }^{1}$ in connection with the broadcasting rights contract in effect, but it was not until 2002 that a formal proceeding was established. The three principal issues of the complaint were: i) the exclusive purchase of the broadcasting rights to the BFL by the largest free-to-air TV broadcaster in Brazil, Globo; ii) the joint sale of those rights by the biggest Brazilian football teams, the "Club of 13," constituting a cartel; iii) the bundling of rights across all five commercial media platforms, free-to-air TV, pay TV, pay per view, mobile, and Internet, ${ }^{2}$ controlled by a single player, i.e., Globo.

After concluding its investigation, SDE called for intervention in the market to limit the exclusive deal. SDE proposed that CADE create two separate packages for free-to-air TV broadcasting rights. The Secretariat also concluded that the five media platforms should be unbundled and sold separately. At the same time, SDE found the joint sale of rights by the "Club of 13" to be an efficient tool, recommending against intervention by CADE.

In October 2010, the Brazilian Competition Agency - $\mathrm{CADE}^{3}$ settled the case a full 13 years after the complaint was first filed.

1 Economic Law Secretariat of the Ministry of Justice.

2 In Brazil, there are as of yet no live mobile or Internet broadcasts of games. Currently, these media platforms are employed to replay goals, show highlights, and offer abbreviated rebroadcasts of games.

3 Conselho Admnistrativo de Defesa Economica Economic Defense Administrative Council. 
The settlement included four points: 1) Globo unilaterally waived the "preference clause" for renewal of the 2012-2014 BLC broadcasting contract. The clause was deemed unreasonably costly to "competition for the market" on the five relevant media platforms. Furthermore, the "Club of 13" pledged not to reintroduce the preference clause in future contracts; 2) the "Club of 13" undertook to award the broadcasting rights to the BLC through an auction with clear and objective rules; 3) the "Club of 13" committed to award separate contracts for the five relevant media platforms to facilitate entry; 4) the winner of the free-to-air TV auction would be allowed to sub-license its broadcasting rights, enabling (sub)licensees to exercise the right to choose which games to broadcast. CADE agreed with SDE that the joint sale of broadcasting rights by the "Club of 13" was efficient.

This paper aims to explain the economic elements underlying the design of the settlement in view of the international experience and the unique features of the Brazilian case.

\section{What is the Antitrust Issue?}

The evolution of sports broadcasting illustrates the consolidation of a typical two-sided market: advertisers buy TV ad time for games on one side to reach viewers on the other side. The bigger the audience, the more valuable ad time for advertisers, representing a typical positive externality from the viewer market to the advertising market. Broadcasters constitute the platform through which externalities are internalized to maximize the value for both markets. It is unclear whether banning exclusivity and expanding the number of broadcasters mediating these two-sided markets contributes to internalizing these externalities.

We examine the impact of exclusive deals on competition in two markets, the football broadcasting market and the general broadcasting market. The potential negative impacts of exclusive deals on the efficiency of the football broadcasting market is likely to be internalized by clubs, suggesting that the private decision to adopt this particular conduct tends toward the social optimum. For instance, if the exclusive broadcaster makes the access of viewers to games very 
expensive, clubs will not have exposure to their fan base, reducing the attractiveness and the value added to the business.

While there may be a convergence between the private and social optimum in the football broadcasting market, this convergence will not occur in the general broadcasting market as long as clubs fail to give adequate attention to this broader market. While football is not an essential facility, it is a powerful tool to attract and maintain audience share not only for football matches, but across the programming grid, heavily influencing competition among broadcasters. ${ }^{4}$

Things get even more complicated when we consider that the exclusive deal was negotiated with Brazil's dominant broadcaster, Globo, which holds almost half of all audience share and earns about $3 / 4$ of advertising revenues in the free to air TV segment in Brazil. ${ }^{5}$

That said, the case at hand is not about football broadcasting in general, but about broadcasting of BLC games in particular. As such, the pertinent question is whether the BLC is important enough to have a significant impact on broadcast competition.

The BLC brings together the country's biggest and most traditional teams, with the largest followings, among them Flamengo, Fluminense, Corinthians, Santos and Atlético Mineiro. Because each game affects every other team's position in the standings, the potential viewing audience extends well beyond state lines and the individual fan bases of teams. This is a key advantage of the

\footnotetext{
4 According to SDE (2008) - Based on the European Commission Statements - football helps build a positive image of the channel for viewers, consolidating brand loyalty: "If a channel usually broadcasts certain programmes, such as the UEFA Champions League, which is in itself a strongly branded event, viewers may develop a habit of screening that channel as their first port of call in determining their viewing choices. The creation of a brand loyalty to a channel encourages viewers to use the channel as "point of reference" for their viewing. This has beneficial effects on other programmes broadcat by the channel". Moreover, as stated by Jeanrenaud and Késenne (2006) "along with first run major box-office films, sport forms the major premium content that channels use as a means of standing out from their competitors and to increase both audience size and subscriber numbers. Sport has a clear advantage over films for the advertisers as it attracts a more homogeneuos audience. The viewers are most likely to be young, male and affluent. This underlines the importance of exclusivity clauses, found in many contracts. In Europe, football rights have been the driving force in the development of pay-TV, and in Britain the acquisition of exclusive rights for live Premier League matches was a key element in Sky's strategy to dominate the satellite television industry." The significance of football broadcasts for TV programming gives full meaning to televised football's description as a "killer application."

5 In addition, the leading sports channel on Brazilian pay TV, SportTV, is part of the Globo conglomerate.
} 
BLC over other competitions, notably the Copa do Brasil (Brazilian Cup), which involves a significantly smaller pool of teams, the state championships, especially Rio de Janeiro and São Paulo, and major international competitions such as the "Libertadores Cup" and the "South American" Cup, in which far fewer Brazilian teams are represented.

The BLC runs longer than any other football competition. In 2009, for instance, the BLC opened play on May 9 and came to a close on December 6, extending almost seven months. The other broacast competitions that year - São Paulo (01/21 -05/03), Rio de Janeiro (01/24-05/03), Copa do Brasil (02/18-07/01), Libertadores (02/10-07/08) and Sul-Americana (08/26-12/02) - were significantly shorter. ${ }^{6}$

The importance of the BLC is reflected in the sums paid by Globo to the participating clubs. In 2005, Globo paid more than 3.5 times the combined total paid for free-to-air rights to the São Paulo State championship, the Copa do Brasil and the South American Cup. From 2005 to 2009, the amount paid by Globo for the right to broadcast BLC rose more than four times, indicating an increase in the economic value of the product. The same trend occurred in the pay TV segment. The per game amount paid to clubs more than doubled between 2008 and 2009. In sum, in view of the importance of the BLC to the Brazilian broadcasting market, the principal antitrust issue in this case involves the impact of vertical foreclosure conduct on the "exclusive deal" between Globo and the Club of 13 against competing broadcasters.

\section{Exclusive Deals in Football Broadcasting: Destroying Compe- tition in the Market or Creating Value?}

In the previous section, we saw that the exclusive deal negatively affects short-run competition as long as Globo's competitors do not have access to a key input, football matches. Nevertheless, be-

6 The strong influence of time duration of the sporting event was stressed by Fikentscher (2006) when addressing the role of the Olympic games: "To be able to develop a brand image for a channel, programming needs to be broadcast throughout the year on a regular basis and must attract viewers not only for one or two competitions but for the event as a whole. Sixteen days of olympic games is just too short a period to guarantee high viewing levels for long periods or for the audience to become accustomed to viewing a particular channel". 
fore resorting to intervention, the dynamics of competition in the market and the potential efficiencies of this conduct must first be addressed.

The fact Globo owns 100\% of the relevant market, thus effectively eliminating all "competition in the market, does not mean an absence of vigorous "competition for the market". It is also possible that to ensure healthy "competition for the market," "competition in the market" should be handicapped. The contest between players for a more valuable business, as embodied in a three-year exclusivity contract for the broadcasting rights to all the matches of a given football competition is likely to produce a more spirited battle in relation to a contract spanning a shorter term or encompassing a smaller set of broadcasting rights, such as the right to broadcast select matches.

Competition for the market in this case may also translate into more money for clubs, which will tend to loosen their purse strings in order to improve their "product." This may include signing better players and/or coaches, enhancing clubs facilities and medical care to players, etc. Moreover, broadcasters may roll out additional offerings that add economic value to the business, including new broadcasting technologies, appropriate scheduling of matches, more relevant information to viewers, more camera angles or more favorable treatment for club advertisers. Furthermore, competition among broadcasters for an exclusive contract may also serve to protect investments by avoiding free-rider behavior. ${ }^{7}$

To address the trade-offs of competition "in" and "for" the market in this segment, we consider the impact of these types of competition on i) revenues and/or other advantages offered by broadcasters to clubs and; ii) incentives for investments by broadcasters.

The impact of competition on club revenues is ambiguous. On the one hand, when there is no exclusivity, the number of buyers of broadcast rights increases, contributing to enhanced revenues. However, non-exclusivity reduces the value that each broadcaster will be willing to pay clubs. The number of viewers and thus the advertising revenues would be split among all broadcasters awarded rights. As long as the expected revenues of the broadcaster in

7 See the survey on the relationship between exclusive deals and investments in general in Whinston (2006, pp. 178-188). 
the two-sided market, viewers and advertisers, is the determining factor of what the broadcaster is willing to pay clubs, the amounts/ advantages offered by each broadcaster would be expected to shrink if exclusivity were banned. Therefore, an increase in the number of broadcasters transmitting matches would translate into more buyers, each of which would pay less, generating an ambiguous net result. As such, it is difficult to establish with certainty which effect prevails, but considering the actual choice of clubs in favor of exclusivity, we can reasonably state that the net effect of exclusivity is to enhance the revenues of clubs.

The analysis of the effect of exclusivity on investment depends on at least three variables, free-riding on broadcasters's investments, the incentive of competition on product differentiation and the Schumpeterian "profit loss" argument. Free-riding depends on the potential externalities generated by competitors' investments. For instance, promotion of the sport of "football," or the BLC in particular, by a single broadcaster may benefit all broadcasters, not only the investor. Non-exclusivity, however, may lead to underinvestment in football or insufficient promotion of the BLC by broadcasters.

In the case of investments in proprietary technology developed by a broadcaster, such as image quality, there is no free-riding. The broadcaster may differentiate its product, generating benefits accruing only to itself. Competition in the market may enhance the rents derived from product differentiation by siphoning off consumers from competitors. Even sunk costs such as specialized cables, microphones, software, technologies specific to football cannot be free-ridden by other broadcasters. In addition, note that in the case of human capital investments such as expert commentators, including former star players, the possibility of some free-riding by other broadcasters, which may have "trained" the commentators in question, is possible. The free-riding is mitigated to the extent other broadcasters will have to offer better salaries to attract the expert commentators.

For both proprietary and non proprietary technology, there is the classical Schumpeterian argument, by which competition in the market reduces expected profits, reducing the incentive to invest. Therefore, in the case of proprietary investment, the net impact of exclusivity is ambiguous. We argue that an inverted " $U$ " relationship between the number of players competing in the market, on the one 
side, and club revenues and broadcaster investments, on the other, is a plausible description of the sector.

It is difficult for regulators to ascertain where the locus of the $U$ curve is and how revenues can be maximized. Clubs themselves may harbor uncertainty about this relationship, although not to the extent regulators do. Given the asymmetry of information between regulators and clubs, State intervention mandating a minimum number of broadcasters may harm competition for the market, which may, in fact, carry greater weight than competition in the market. Banning exclusivity could deteriorate the property rights of clubs, harming the economic value of the business and reducing expected club revenues and broadcaster investments.

The SDE did not propose a mere ban on exclusivity. Rather, it recommended imposing a constraint on the freedom of clubs to sell broadcasting rights by facilitating competition in the market. The SDE put forth a plan to create two free-to-air TV broadcasting rights packages. ${ }^{8}$ The first package would involve games played on Wednesdays and Sundays, while the second package was intended for matches played on Thursdays and Saturdays. CADE found that the risk of this type of intervention in the BFL's business model, specifically the potential reduction in club revenues, was too high. ${ }^{9}$ CADE opted for a softer approach.

A related trade-off considered in this case concerned the choice between broadcasting games on free-to-air or pay TV. As Gratton and Solberg (2007) report, deregulation in Europe led to the migration of sports broadcasting from free-to-air to pay TV, translating into a significant increase in sports programming on TV. In Brazil, Globo

8 This approach was inspired by the UEFA Champions League, the German Bundesliga, the British Premier League and the American National Football League. The model adopted by UEFA, the Bundesliga and the Premier League stemmed from a previous challenge brought by the European Competition Commission. In the case of American Football, the sale of broadcasting rights in packages has been accomplished voluntarily. In fact, the latter case provides the basis for the SDE's argument that the sale of sports broadcasting rights in packages adds value to the business. The SDE's position would indeed find firm footing if the Football Association were to choose this model of its own accord. However, it is not clear that the value of the business would be bolstered by having the State impose the sale of broadcasting rights in packages against the will of the Football Association. For in the end, it is unlikely the regulator has better information at hand than the Association to make a decision of this nature and magnitude.

9 The SDE did not recommend any constraint on the ability of a single buyer to purchase the two packages, a solution supported by Record. The primary concern was that a constraint of this nature could lead to a "buyer cartel" of broadcasters. 
transmits two games a week on free-to-air TV, or 10\% of all BFL games held each week. Until just a few years ago live TV broadcasts were not available for all games. By contrast, today live telecasts of all BFL contests are available, either on free-to-air TV or "pay per view," an achievement Globo attributes to exclusivity.

A ban on exclusivity would, in all likelihood, lead to more free-toair TV broadcasters, offering greater access to people who cannot afford pay TV. This is significant in a country like Brazil in which pay TV subscription rates are only 5.1 per 100 inhabitants, while the percentage of households with TVs is over 95\%. The bottom line is that transmitting more games on free-to-air TV will reduce the attractiveness of the most profitable pay TV and pay per view packages. At the limit, banning exclusivity could jeopardize pay per view and the live broadcast of all matches, eroding the economic value of the BFL. CADE, Globo and the Club of 13 agreed that this trade-off should not be contemplated in the settlement and that the parties should be free to their own strategies for growing the business, whether through free-to-air TV or pay TV. ${ }^{10}$

Based on these various considerations, CADE was not willing to ban or significantly constrain exclusive deals in connection with football broadcasting rights in order to foster competition in the market, opting, instead, for a softer approach center on competition for the market.

\section{Efficiency of the "Club of 13 "}

The European Commission indicated that centralizing the negotiations on the broadcasting rights for individual clubs in a single entity such as the Club of 13 could have a negative impact on competition. On the other hand, the EU recognized that centralization is a com-

\footnotetext{
${ }^{10}$ Jeanrenaud and Késenne (2006) defines the trade-off between free-to-air and pay TV in the following terms: On the one hand, the marginal cost of serving an additional viewer is zero, making the free-to-air TV model, with zero price to viewers, more appropriate. On the other hand, pay TV has a greater capacity than free-to-air TV to identify viewer preferences, allowing for efficient price discrimination and bundling strategies. In this light, the authors argue, "given the present state of knowledge, it is not possible to say which of the forms of market failure leads to the great welfare loss," offering, as such, a possible justification for opting for neutrality.
} 
mon practice in the media market and an important instrument for boosting club revenues.

The main problem is that centralizing the process in a single body like the Club of 13 reproduces many of the characteristics of a cartel. In this case, the problem is not the "unified" price of broadcasting rights for individual games to a level closer to a monopoly. The Club of 13 bundles all BFL matches and sells them for a single aggregate price. Therefore, the stability of the "cartel" can be taken for granted, as a single price is easier to manage than several prices. Because clubs do not set prices or negotiate separately with broadcasters, there is no opportunity for deviating from the cartel rule.

On the other hand, classifying the Club of 13 as a typical cartel is to disregard the distinctive features of the sector. In contrast to other industries, the "product" cannot be produced by a single club. It is by definition a "joint production" of at least two clubs, a common trademark of sports in general.

Furthermore, games played outside the bounds of a formal competition will generally have a lower value than games played within the scope of an official league. In other words, the fact that a particular contest is part of a championship enhances its economic value. A football championship can be understood as a multiplant firm rather than a cartel. Each game can be taken as a plant that produces part of the total product of the company. According to Gerrard (2006), it can be described as "cooperative competition, in which clubs cooperate in economic terms to produce championships". What is being sold is competition itself, which is a common feature of professional sports. ${ }^{11}$

Another feature of this market relates to the important role the uncertainty of match results plays in the business. Individual games and championships with highly predictable results jeopardize fan interest, even where a particular fan's team is the odds-on favorite to win or emerge as champion. Thus, a competitive balance among clubs is essential to ensure greater uncertainty with respect to results, attracting more fans to games and generating more advertising for clubs and broadcasters. This balance depends on distributing

11 Tonazzi (2003), as quoted in Jeanrenaud and Késenne (2006), challenges this view of leagues as a single economic unit arguing that "clubs are separately owned and benefit from a large commercial and organizational autonomy." 
good players and quality facilities among teams. It is also contingent on distributing resources among clubs. The problem is that clubs with larger fan bases are able to draw more resources from fans (e.g., ticket sales) and advertisers. This provides larger clubs with growth opportunities not available to smaller teams, jeopardizing competitive balance.

According to Gratton and Solberg (2007), the joint sale of broadcasting rights allows at least some redistribution of resources among clubs. Even if the larger teams receive a larger proportion of the association's revenues, the smaller teams benefit from the externalities generated by the additional value the major clubs bring to the the table. In other words, clubs with the largest fan bases generate positive externalities to clubs with smaller followings. Therefore, the joint sale of broadcasting rights by the Club of 13 may benefit the competitive balance of the teams. Gerrard (2006) confirms this assumption by demonstrating that the concentration index is higher in countries opting for the individual sale of rights.

Note that externalities are partially internalized by the major clubs. To the extent a substantial improvement in one club may reduce public interest in the competition, the marginal returns for signing top-flight players decreases. To be sure, internalization is far from complete and the interest of each individual club is to free-ride on the provision of the collective benefit of "competitive balance." 12 But when clubs join in arrangements such as the "Club of 13," freeriding is mitigated, indicating that the arrangement brings potential efficiencies. ${ }^{13}$

Joint sale also saves transaction costs compared to the alternative of individual negotiations with broadcasters. Club by club negotiations raise questions as to how to define property rights when two

${ }^{12}$ Gratton and Solberg (2007) summarizes this conflict between individual and collective rationality of clubs: "whereas each club can maximize its attendances by maximizing the number of wins, the league as a whole may suffer by a reduced uncertainty of outcome....the uncertainty of outcome dimension represents a two-edged sword for teams and their supporters. Although both of them prefer to win, many find it boring if one or a few teams become too dominant". The authors add that "the peculiar economics of professional sports" is such that clubs "have an interest in upholding the economic health of their rivals".

${ }^{13}$ Gratton and Solberg (2007) recognize that it is possible to have other intruments than centralized negotiation to improve resource realocation among clubs. However, arrangements like the Club of 13 make it more feasible: "since the main purpose with agreeing collective sale procedures often is to redistribute income, the clubs involved in such deals are probably more willing to share income than clubs that negotiate their rights individually." 
clubs that have awarded their respective rights to different broadcasters face each other. General rules like "the home team retains the property right" or "the game is subject to black out" may be defined prior to the season. Game by game negotiations are another possibility, leading to higher transaction costs. In any event, individualized negotiations tend to hurt pay per view business, as today most viewers tend to purchase the option to select from all available games. $^{14}$

According to Gratton and Solberg (2007), in the UK, the Restricted Practice Court (RPC) accepted the collective negotiation, while, however, finding that the deal fell within the definition of cartel behavior, based on the redistribution toward small clubs. In Germany, the Bundesliga was also allowed to market broadcasting rights collectively. In both cases, the EU required the association in charge of the broadcasting rights to split them up into packages. France attached so much importance to collective negotiations that they were mandated by law.

The European Commission (EU) also recognized the potential virtues of centralizing the negotiation of broadcasting rights under one single entity within UEFA. Nevertheless, the EU also argued that the attendant virtues cancel out when the single entity sells all available rights to a single broadcaster for several consecutive years as in Brazil. Thus, the centralized negotiations under one entity are only considered a problem when associated to an exclusive deal with a single broadcaster. To address the problem, the European Commission persuade UEFA to divide its key rights in two packages sold simultaneously, thereby allowing the league to preserve centralized negotiations.

On the other hand, in Italy, the Italian Competition Commission mandated that clubs sell broadcasting rights individually. Consistent

\footnotetext{
${ }^{14}$ Even considering that arrangements like the Club of 13 have the potential to redistribute resources among clubs, coexistence among organizations is not always peaceful. Horowitz (1999) shows that two of the major American college football conferences, the Big Ten and the Pac Ten, formed a separate entity outside the scope of the NCAA (National Collegiate Athletic Association) and the CFA (College Footaball Association). The primary complaint lodged by CFA members against the NCAA was "their limited telecast-and-revenue opportunities." The NCAA threatened CFA members with reprimand and expulsion. CADE's case did not involve boycott conduct among clubs, but centered on whether centralized negotiations by clubs were unlawful. Following the settlement reached in Brazil, some clubs challenged the rules of the settlement and the Club of 13 ruling, opting for individual negotiations, principally with Globo.
} 
with the "redistribution of resources" and "free-rider" arguments, this policy increased inequality among teams. Juventus earned more than the bottom nine clubs, driving the smaller teams to threaten a boycott of the league.

In Spain, Real Madrid and Barcelona negotiated their rights individually, while the remaining 18 clubs negotiated collectively. The result is that the two biggest clubs earned about $37 \%$ of the total revenues collected by clubs. This stands in sharp contrast to the UK where collective negotiations restricted full take of the country's two most important clubs, Manchester United and Arsenal to $15 \%$ of total revenues.

In view of this analysis, CADE did not challenge the Club of 13 arrangement.

\section{Segmenting Media Rights}

A key point of the SDE's analysis is that the bundling of the five media platforms (free to air TV, pay TV, pay per view, mobile and Internet) favored Globo, as it represented the only broadcaster with operations on the five media platforms. The SDE stressed that bundling would increase on barriers to entry in the market and recommended unbundling of the five platforms. An example occurred in 1997 when SBT bid higher than Globo, but was passed over by the Club of 13, because it only offered free-to-air TV services and lacked a pay TV package. In that same year the Club of 13 also excluded Band because the network's pay TV associate, TVA, was unable to provide pay per view at that time.

On the other hand, in 2012 successful associations between free-toair broadcasters and other media platforms may be more likely than 14 years ago when the lawsuit against Globo and the Club of 13 was filed. So, a free-to-air TV broadcaster lacking a pay TV arm can now link up with pay TV providers against broadcasters operating a more complete media package. In Brazil, a free-to-air TV broadcaster such as Record or SBT can team with pay TV channels, including ESPN, to bid for all TV rights. They can also consider partnerships with telecom operators ranging from $\mathrm{Oi}$ and, Vivo to Telefonica or even pure Internet providers such as UOL. 
A recent example of a successful bidder without the full package of media platforms that was able nonetheless to secure the rights to the last Olympic Games was Record network. In fact, the International Olympic Committee was not interested in individual media bids, preferring to sell its broadcasting rights as a single media package to a free-to-air TV broadcaster, Record. Interestingly, Record sublicensed the rights to pay TV and pay per view to Globo, the losing bidder. In this light, the bundling of media does not necessarily indicate a clear preference for broadcasters operating in all media segments.

Again, it is important not only to address the anticompetitive impact of unbundling, but also how media unbundling affects the football broadcasting rights business.

When a seller chooses between selling a given set of objects together or separately, he first considers whether the potential buyers have different valuations for those objects. If each object has a single potential buyer which attaches the greatest value to the object in question, a strategy of individualized sales may enhance the revenues collected. In the case of soccer broadcasting rights, it is highly possible that the most efficient TV broadcasters are not the most efficient Internet providers. Similarly, both of these are not likely to be the most efficient providers of mobile platform football image services.

Furthermore, media complement and substitute each other. In cases in which they are complementary, the value of a bundled subset of media is higher than the value of this subset sold separately. Two examples of complementarities are relevant: i) Revenue cannibalization between media. When two or more media are acquired jointly, the winning bidder is able to internalize and minimize the negative externalities of one media over the other by enhancing their joint value; ii) Each viewer holds a different preference regarding distinct media. Different commentators in distinct media may be important. ${ }^{15}$ Some viewers full match broadcasts on TV, particularly those involving the leading clubs. Other may merely only want to catch the highlights on the Internet, mobile devices, and TV media, inclu-

${ }^{15}$ In Brazil, for instance, there are two types of viewers in regard to their attitudes toward Globo's lead football commentator and the one of the country's most famous sports media personalities: a) the ones who love him; b) the ones who hate him, in what constitutes a typical horizontal differentiation. 
ding after match times. When acquiring more than one media, the broadcaster is able to offer a more complete package of services to viewers, enhancing the value of the bundled media package.

The principle of substitutability applies as well. As long as the access to a broadcaster provided by the first media is relatively more important than subsequent media, each buyer will be willing to pay more for the first media and less for the others. However, as the broadcaster can allocate different games in each media, substitutability may be significantly restricted, since each club's fan base will be redirected to those media broadcasting their teams contest.

It is quite difficult to address the relative importance of each factor in an optimum media fragmentation scenario. On one hand, each bidder has distinct valuations of individual media and that media substitutability pushes the optimum to media unbundling. On the other hand, midia complementarity drives the optimum toward media bundling. Competition policy also points to media unbundling as a means to facilitate entry into each platform, a factor that becomes less important as associations between different media owners emerge. CADE's settlement with the Club of 13 on media unbundling aimed to conciliate these effects. The Club of 13 undertook to permit bids for individual media. However, the Club of 13 was not prohibited from selling more than one media, including all five media, to the same bidder, depending on the value of the bids. Indeed, the Club of 13 was not even prohibited from accepting joint bids for more than one media, or a joint bid for all five media. ${ }^{16}$

A potential critique is that unbundling without constraining the capacity to buy all media may generate the same outcome as allowing bundling all media for joint sale. The problem with imposing constraints on the broacaster in buying all media, as in the UK case, ${ }^{17}$ is that once a bidder has bought the maximum allowed media, compe-

\footnotetext{
${ }^{16}$ Assume that bidder A bids $\$ 1,000.00$ for each one of the five media separately, generating $\$ 5,000.00$ in revenues. Assume that bidder B makes a joint bid of $\$ 10,000.00$ for all five media. If the Club of 13 accepts both the individual bids of $A$ and the joint bids of $B$, it will be in a stronger position to grant broadcasting rights to $\mathrm{B}$. On the other hand, if the sum of the individual bids, made by up to a maximum of five bidders, amounts to, say, $\$ 12,000.00$, the Club of 13 will prefer selling the respective rights to individual bidders.

${ }^{17}$ The UK offers an important example of constraint on the capacity of a single broadcaster to buy all packages/media. The Premier League selected six packages of rights and a "single buyer rule," by which as given buyer could purchase no more than five packages, constituting a mild constraint. Bundled bids were also prohibited.
} 
tition for the market in all remaining media is harmed. Worse yet, this could drive broadcasters to agree on the specific packages each one receive, substantially impacting competition for the market.

\section{Auctioning Broadcast Football Rights}

According to Gratton and Solberg (2007), the concession of exclusivity rights in broadcast sports has been done more and more through auctions. This mechanism has boosted revenues in sports. CADE's agreement with the Club of 13 included a provision requiring that the broadcasting rights for the BLC be awarded through a competitive bidding with clear and non-discriminatory rules, without binding the Club of 13 to any specific type of auction.

One of the main objectives of auctions is to maximize revenues to the seller. Another key goals is to allocate the "object" to the bidder that attaches the most value to that object. Where the object of the auction is a business, as is the the case with broadcasting rights, bids are correlated to the expected profit of the bidder, which is also correlated to the value the bidder brings to society when running the business. When these correlations are close to "1," the target of raising revenues in the auction and allocating the business to the bidder which attaches the greatest value to the business and offers added value to society will coincide in the auction mechanism.

The problem is that those correlations are not always perfect. An auction based purely on the monetary value of bids may maximize auction revenues, but does not allocate the business to the bidder offering the greatest value to society. For instance, if the winner of the auction of a business is able to enhance its market power, the auction procedure is likely to maximizes revenues for the seller, but not contribute to the welfare of society. Indeed, the winner will include monopoly rents in its optimal bid, thus raising the bid.

It is also possible that the seller could retain an interest in a given variable related to performance of the business. The bidder better suited to achieve the required performance may not accrue the highest profits, and, as such, put forward the highest bid. Thus, the seller may wish to adapt the auction mechanism to this target. This may include performance targets related to a variable of interest in 
return for a future commitment from the winner and/or as part of a set of award criteria.

In the case of football broadcasting rights, clubs are interested in the capacity of broadcasters to keep and enhance the number of viewers. First, because they share the ex-post income from pay per view in Brazil (clubs will remain direct partners of the broadcaster in this case) and, second, because more fans watching games ensure football and each broadcast club's "brand" remain highly valued. Enhancement of the brand carries value for clubs, as well as provides a means to attract advertisers and, by extension, more fans and revenues. This is partially internalized in the bids, as more expected viewers increase the amount of money broadcasters are willing to spend on these rights. However, it is not fully internalized since broadcasters and clubs contract independently with advertisers. Broadcasters simply do not internalize the income that clubs receive directly from their advertisers within their bids. In this light, clubs may be more interested in the number of viewers than broadcasters. Thus, it is possible that the winner of the auction, which is capable of paying the highest amount to the respective clubs may generate the most for clubs.

It is important to consider whether specific broadcasters are better able to enhance the number of viewers compared to other broadcasters. If viewers are more loyal to the program "football" than to the broadcaster, advertisers and clubs become more indifferent in regard to which broadcaster will be chosen. However, Globo argues that they "advertise games" throughout its programming grid. Since Globo has the highest average audience, it can attract more viewers than any other network, enhancing value for advertisers and clubs (and their own advertisers). So, what is relevant here is to ascertain whether football fans depend on TV advertising to get information and keep or enhance their interest on games.

It is possible that the marginal impact of football on broadcast earnings depends on the size and/or overall market share of the broadcaster. If the inclusion of solid new programs have decreasing returns as the number of good programs grows, it is possible that larger broadcasters will increase their audience by a smaller percentage than small broadcasters. This means that although larger broadcasters can attract more audience than smaller broadcasters, the mar- 
ginal increase in audience share of the former is smaller than the latter. Therefore, broadcasting rights may be less valuable for a larger network than a smaller broadcaster in view of decreasing returns. The result is that when the award criteria is merely the highest money bid proposal, the winner may be a broadcaster that attracts less audience, decreasing the number of football viewers and the advertising income of clubs.

In the UK, Gratton and Solberg (2006) consider the case of rugby. The transmission rights were transfered from the $\mathrm{BBC}$ to BskyB, after the broadcaster won the competitive bidding launched by the League. The problem was that BskyB proved less efficient in attracting audience share than the $\mathrm{BBC}$, as reflected in the drop in average audience totals from 3 million to 150,000. When the contract with BskyB ended, the broadcasting rights for rugby reverted back to the BBC.

Other issues like minimum quality requirements may be key to clubs' interests and thus affect the optimum award criteria. Once more, the complexity of those issues made CADE unwilling to arbitrate the auction criteria, which was left to the Club of 13. The settlement simply indicated the need of objective, clear and non-discriminatory rules. The terms of the settlement rendered the clubs free to include, for instance, audience targets in the auctioned contract and/or include these as part of the award criteria. ${ }^{18}$ This enabled the correction of non internalized externalities for auction procedures based solely on monetary factors. According to Jeanrenaud and Késenne (2006), "the federations know - or ought to know - that it is in their interests to maintain a wide audience in order to guarantee the future popularity of the sports they represent. For this reason, rights do not always go to the highest bidder. This is illustrated by IOC's policy statement on this issue: "The fundamental IOC television policy as set forth in the Olympic Charter is to ensure maximum presentation of the Olympic Games to the world. To ensure the widest possible television audience for the Olympic Games, Olympic

\footnotetext{
18 The problem of including the variable of concern as a commitment established ex-ante or as part of the award criteria is that they may not be credible ex-post, a typical Williansom critique when there is asset specificity from both sides. The punishment for non-fulfillment of the commitments ex-post may not be feasible or be very costly. To avoid this problem, the seller may adopt rules of bidder eligibility based on some present observable variable, perhaps based on past performance, related to the variable of interest. In the case of broadcasting rights, the Club of 13 could have used past audience performance as a means of defining rules of eligibility in the award criteria.
} 
broadcast rights are sold to broadcast networks that can guarantee the broadest free-to-air coverage".

Through 2009, the auctions held by the Club of 13 were based on the highest offer. In 2011, the Club of 13 continued to base its award criteria on the highest financial bid. However, the Club of 13 added a 10\% advantage to Globo in view of the "Globo's support to Brazilian football over the past 25 years and the wide exposure the networks audience share offers club sponsors". The question is whether this advantage fits the terms of the agrement with CADE.

CADE was consulted by the Club of 13 before the competitive bidding procedure and argued that the 10\% advantage would be discriminatory and an actual preference to Globo. Thus, the Club of 13 waived this advantage. The main problem is that the "10\% Globo plus" was not based (at least explicitly) on any objective and observable criteria. However, the Club of 13 could have introduced an eligibility rule based on audience. However, if Globo were to fulfill the criteria, CADE would likely deem this discriminatory. The introduction of audience parameters based on quantitative evidence in the award criteria jointly with the money paid could be an interesting approach to the challenges at hand mentioned above and contribute to fulfillment of the settlement requirements.

Another important problem concerning auction methodology in this sector is the winner's curse. Broadcasting rights offer substantial common values, since part of the value of this business is independent of the individual characteristics of the bidders. The huge number of soccer fans in Brazil and the established tradition of Brazilians to watch broadcast games on TV is a common feature for all broadcasters and do not depend on their specific efficiency at least in the short and medium run. Associating this common value characteristic to the fact that the incumbent, based on its historical experience in this market, may enjoy a significant information advantage over other broadcasters, the existence of a winner's curse ${ }^{19}$ is plausible. By anticipating this, other bidders will be less aggressive in their bids. One alternative to mitigate this problem would be the inclusion of revenue sharing agreements among clubs and the winning broadcasters ${ }^{20}$ allowing for better risk allocation among players.

${ }^{19}$ Gratton and Solberg (2006) believe that a winner's curse occurred in many cases in Europe. One example involved Canal Plus's bid for the French League's rights.

${ }^{20}$ This may result in a lower up front payment bid by broadcasters in the auction. 
The revenue share could even become part of the award criteria. In Brazil, the contract in the pay per view midia already includes a revenue sharing clause.

\section{Competition for the Market and Right of Preference}

A preference clause seems to have helped Globo to maintain its status as the lone broadcaster of the BFL from 1997 to 2011. The preference clause is a typical English clause. Every bid made by a broadcaster to the clubs must be submitted to Globo. If Globo matches the bid within 30 days, it wins the contract. This increases the probability of extending the three-year exclusivity term to six years, mitigating "competition for the market" in favor of Globo.

Therefore, as with the three-year exclusivity provided for in the broadcasting rights contract, the preference clause can have a positive impact on club revenues and the non-appropriable investments of broadcasters. In regard to club revenues, as long as the preference clause enhances the expected time of exclusivity, the value of the business will increase for the broadcaster, which will be more willing to pay for the broadcasting rights in the first place. We can say, therefore, that the preference clause has a "price."

However, the positive effect of the preference clause on clubs seems to be weaker than the impact of the three-year exclusivity to the extent agents discount the future (beyond three years). In other words, the return on club revenues from increasing the exclusivity period decreases. Furthermore, since the result of the auction remains uncertain, the preference clause may be priced less than would be a standard contract extension.

There is a general tendency for the incumbent and the entrants to put forth lower bids in the presence of the preference clause. The beneficiary of the clause, Globo, has an incentive to submit a low initial bid, given that it will always have the opportunity to best the competition by triggering the preference clause. Theoretically, Globo could bid zero in the first auction round at no cost, knowing that it will have a second chance. So, while the preference clause may have boosted the bid offer in the first auction, it may well have reduced the final proposal in the following auction. The process constituted 
a long/short run trade-off, with the "Club of 13" opting invariably in favor of the short run.

The preference clause also creates a low incentive for competitors to make competitive bids, since they anticipate that Globo will have a chance to match their proposal, while they will be powerless to react. In short, they would be merely revealing strategic information as to the value of the respective rights. So, there is a strong tendency for all bidders, incumbent and entrants, to bid lower than they would if there were no preference clause.

Considering the preference clause, the problem of the winner's curse in the auction becomes more acute: other bidders anticipate that if Globo does not use its preference ex-post, it is very likely that they will have overestimated the actual value of the rights and exagerated the bid amount. Unless the entrant bidder has a private value substantiallyn excess of the value of the incumbent (common and private) and is aware of it, a classical winner's curse problem will emerge. Again, in anticipating this entrant bidders tend to be less aggressive in the bidding stage. The probability that an entrant will be successful in the competitive bidding procedure, even if more efficient than the incumbent, is reduced with the preference clause.

Therefore, the preference clause reduces the vigor of competition for the market, with three types of foregone benefits. First, if the most efficient player is no longer the incumbent, the preference clause reduces the likelihood that this most efficient player will win the auction in view of the winner's curse and the incumbent's information advantage. ${ }^{21}$ This represents a potential loss of efficiency in the market. Second, as argued above, preference clauses may reduce expected revenues for clubs in auctions held following their adoption, reducing their capacity and incentive to spur investments to enhance the event.

Third, in the long run competition through innovation among broadcasters can occur only if there is competition for the market. As long as preference clauses reduce the opportunities for entrants, the incentive to offer enhanced services at the time of contract shrinks.

${ }^{21}$ Preference clauses are better than longer exclusivity periods for competition since they potentially, at least, provide for replacement of the incumbent when a very efficient entrant emerges. 
All three inefficiencies are part of the objective function of the Club of 13. This association compares the costs against short-run gains on the first contract when the preference clause was priced and potential positive effects on broadcaster investments accounted for.

There is a fourth inefficiency that is not part of the Club of 13's objective function and may, as such, represent a gap between the private and the social objective function. By reducing the chance of alternative broadcasters, the preference clause extends the short run competition problems of exclusive deals in the broadcasting market over a longer time. As long as alternative broadcasters lack the opportunity to obtain rights, a three year lockout to this important input will extend to the long term. At the same time, as we saw above the positive impacts on the short-run revenues and investments of clubs tend to be lower than the effects of the threeyear exclusivity period.

The bundling of media magnifies, further, the damage to competition for the market from the preference clause. Again, as long as the preference clause makes it more difficult for a relatively more efficient player in the provision of a single media platform to gain access, the efficient delivery of media will be jeopardized as well.

Thus, the trade-offs involved in the preference clause more closely approximate those verified in the three-year exclusivity period. Yet, the cost-benefit analysis is more benign to the three-year exclusivity period (restraint of competition in the market) than the preference clause (restraint of competition for the market). The analysis suggests that an intervention to suppress the preference clause may not be as damaging to the business model for soccer broadcasting rights than a direct ban on short run exclusivity.

By 2010, the Club of 13 began signaling to CADE and to the market that the preference clause was no longer a welcome provision, perhaps indicating that the entity had become more forward looking. Although it is neither a necessary or sufficient condition for an antitrust intervention, the shift revealed to CADE that an intervention capable of harming the BLC's business model posed a smaller risk than in the past when the clause represented a source of mutual interest for Globo and the Club of 13. Therefore, while the Club of 13 continues to tout the exclusive deal as a functional strategy for 
the market's business model, the same conclusion cannot be drawn from the preference clause.

\section{The 2011 Brazilian Football League Negotiation: Did the Set- tlement Work?}

The negotiations on the broadcasting rights to the BFL for the 2012 - 2014 period were not launched until early 2011. Some of the leading Club of 13 teams, including Corinthians, pressed the group to maintain its contract with Globo without a competitive bidding procedure. The main arguments for staying with Globo centered on the newtwork's expertise and ability to attract larger audiences than any of the other broadcasters.

The gridlock between the Club of 13 and a number of the major clubs triggered the group's fragmentation and a series of individual negotiations with Globo. The Club of 13 insisted on the competitive bidding procedure and awarded the broadcasting rights to a smaller broadcaster, Rede TV. However, due to the decision of a majority of clubs to negotiate separately with Globo, the Club of 13 backed out of the contract with Rede TV!

Our view is that fragmentation does not represent the optimal outcome to provide efficiency to the market and the associated arguments expounded in section IV. While smaller teams will likely pay a price, an extra transaction cost is sure to apply any time two clubs attached to different broadcasters face each other.

The case offers an interesting antitrust issue. A set of bilateral negotiation between Globo and Brazilian teams outside the framework of the Club of 13 circumvented, in practice, the settlement between CADE and the Club of 13. In short, the actions of a minority of clubs effectively doomed the settlement. The question is whether the separate negotiations entered into by individual clubs which ultimately undermined the settlement constitute an antitrust case. In fact, the fragmentation of negotiation weakens the case for antitrust intervention, as each broadcaster will compete for the market "club by club." A "club by club" competition for the market could generate competition in the market, resembling the SDE's proposal to break the BFL's stranglehold . Each broadcaster would define its 
own standards of broadcasting, including technologies, commentary, press coverage and game schedules. Clubs would be more able to compare the services offered by different broadcasters, enabling more informed choices. Yet, ultimately the efficiencies afforded by exclusivity would be lost.

Although circumvented by Brazilian clubs and Globo, the settlement had the virtue of shaking up the market. Two additional broadcasters, Record and Rede TV!, expressed an interest in the business and began to submit offers to individual teams. This could have changed the status quo of the negotiation in favor of clubs.

The fact that the fragmented negotiating process ended with every club concluding a deal with a single broadcaster, Globo, seems to indicate a shared belief that Globo's remains far ahead of its competitors in regard to the efficiencies it offers, namely the capacity to attract audience share, offer quality TV broadcasts and generate advertising revenues. However, Globo's advantages could have been contemplated in the selection process by incorporating a score system, as proposed by Carrasco and Mello (2011). Under CADE's settlement with the Club of 13 , nothing precluded the Club of 13 from awarding scores to bidders based on the fulfillment of particular benchmarks. In fact, CADE recognized that the criteria for awarding of the contract should be left to the discretion of the Club of 13, including the application of quality requirements not captured in purely financial bids. That said, the Club of 13 preferred to consider only the highest financial bid.

In sum, the perceived private cost of an antitrust intervention that reduces the likelihood of Globo emerging as the winner is high. Even when considered in the light of the soft approach adopted in the settlement with Globo and the Club of 13, particularly when compared to the more intrusive solution proposed by the SDE, it is possible that the sector is simpy not mature enough for an antitrust intervention, posing a serious risk of disruption to the Brazilian football business model and that of the Brazilian Football League, in particular. 


\section{References}

CADE: Report to PA 08012.006504/97-11. http://www.cade.gov.br/temp/D_D000000562791945.pdf

CADE: Consent Decrees with Globo and Club of 13 in PA 08012.006504/97-11. http://www.cade.gov.br/ temp/D_D000000561841435.pdf and http://www.cade.gov.br/temp/D_D000000561831135.pdf

Carrasco, V. and Mello, J.M.P.: Desenho de Mercados e o Fracasso do Leilão dos Direitos de Transmissão do Futebol Brasileiro. Mimeo, PUC/RJ, 2011.

Fikentscher, A.: "Joint Purchasing of Sports Rights: A Legal Viewpoint." In The Economics of Sport and the Media. Edward Elgar, 2006, eds. Jeanrenaud, C. and Késenne, S.

Gerrard, B.: "Competitive Balance and the Sports Media Rights Market: What are the Real Issues?" In The Economics of Sports Broadcasting. Routledge, 2006. eds. Jeanrenaud,C. and Késenne, S.

Gratton, C. and Solberg, H.: "The Economics of Sports Broadcasting." Routledge, 2007.

Horowitz, I.: "The reasonableness of horizontal restraints: NCAA." In "The Antitrust Revolution" $3^{\text {rd }}$ ed. Eds: Kwoka, J. and White, L. 1999.

Jeanrenaud, C. and Késenne, S.: "Sport and the Media: An Overview." In The Economics of Sport and the Media. Eds. Jeanrenaud, C. and Késenne, S. Edward Elgar, 2006.

Secretaria de Direito Econômico: Report to PA 08012.006504/97-11. http://www.cade.gov.br/temp/D_ D000000362471992.pdf

The Economist: "The Killer App." April 29, 2010.

Whinston, M.: "Lectures on Antitrust Economics.” Cairoli Lectures. The MIT Press, 2006. 